\title{
塩酸タムスロシン服用患者の意識調査に基づく剤形についての問題点
}

\author{
緒方郁子, ${ }^{*}, a$ 山崎啓之, ${ }^{a}$ 霍田敦子, ${ }^{b}$ 津㠃祥一郎, $b$ \\ 石松隆志, $b$ 平山英雄, ${ }^{b}$ 瀬尾 $\quad$ 量 ${ }^{a}$
}

\section{Some Problems for Dosage Form Based on Questionnaire Surveying about Compliance in Patients Taken Tamsulosin Hydrochloride}

\author{
Ikuko Ogata, ${ }^{* a}$, Keishi YAmasaki $^{a}$, Atsuko Tsuruda ${ }^{b}$, Shoichiro Tsuzaki ${ }^{b}$, \\ Takashi ISHIMATSU ${ }^{b}$, Hideo HIRAYAMA ${ }^{b}$, and Hakaru $\mathrm{SEO}^{a}$ \\ ${ }^{a}$ Laboratory of Clinical Pharmaceutics, Faculty of Pharmaceutical Sciences, Sojo University, \\ 4-22-1 Ikeda Kumamoto City 860-0082, Japan, ${ }^{b}$ Hirayama Urological Clinic, \\ 1-24-32 Hakemiya, Kumamoto-City 861-0864, Japan
}

(Received March 29, 2007; Accepted October 6, 2007)

\begin{abstract}
After the dosage form of tamsulosin hydrochloride was changed from a capsule to on orally disintegrating tablet (ODT, Harnal ${ }^{\circledR} \mathrm{D}$ ), we often received patient complaints and noted an increase in noncompliance with medication regimens. The change in dosage form appeared to cause poor compliance by patients who had become accustomed to the light pink/white capsule over many years. Therefore, we carried out a questionnaire survey of patients taking the ODT form to determine the effects of changing the dosage form and the usefulness of the ODT. Most (92\%) of respondents took the ODT with water. In addition, $16 \%$ missed taking the medicine after the change in dosage form. ODT is a dosage form that is easy to take for patient with dysphagia, or those on restricted water intake. However, it appears that elderly men and patients with visual disorders cannot distinguish the ODT from other medicines and this affects patient compliance. In conclusion, all pharmaceutical companies should consider the design of medications in terms of coloration, indications, or shape in anticipation of the aging society in future, so that patients can distinguish them. Furthermore, sufficient pharmaceutical care is needed to improve both compliance and safety management for the elderly.
\end{abstract}

Key words_— tamsulosin hydrochloride; orally disintegrating tablet; questionnaire survey; compliance; color

\section{緒言}

ハルナール ${ }^{\circledR}($ 塩酸タムスロシン) は 1993 年 8 月 より男性の前立腺肥大症に伴う排尿障害の治療薬と して汎用されている. 高齢男性人口の増加と前立腺 肥大症に対する社会的な認識の向上により排尿障害 の改善を求めて医療機関を受診する患者が増加して おり, ${ }^{1)} \alpha_{1}$ 受容体遮断薬の二ーズは益々高まってき ている. ハルナールは当初カプセル剂で発売され ていたが 2005 年 7 月以降は口腔内崩壊錠へ剂形変 更となつた。口腔内崩壊錠は高齢化社会を迎えた現 在，高齢者又は嚥下困難な患者でも服用し易く，ま た水分制限を余儀なくされている患者でも服用が可 能な患者にやさしい剂形という利点が謳われてい

$a$ 崇城大学薬学部医療薬剤学研究室, $b$ 医療法人英山会 平山泌尿器科医院

*e-mail: iogata@ph.sojo-u.ac.jp
る. ${ }^{2,3)}$ しかし一方では塩酸タムスロシンの剤形変更 後，1）体調（排尿状態）が変化した，2）錠剤が白色 になつたため他剤と区別がつき難く飲み間違いが増 えた，3）水なしで服用することに不安を感じる等, 口腔内崩壊錠への剂形変更による不満を訴える声が 患者から聞かれるようになった。塩酸夕ムスロシン 発売後 10 年以上が経過した現在，薄桃／白のカプ セルを服用してきた患者において剂形変更が服薬に 対する不安及びコンプライアンスの低下を招き，患 者の体調（排尿状態）に影響を与えている可能性が ある. また口腔内崩壊錠は水なしでも服用できると いう利便性は本剤でも活かされているのか，その使 用実態報告は少ない。そこで剂形変更による様々な 影響，口腔内崩壊錠の有用性を検証する目的で患者 意識調査を実施したので報告する. 


\section{対象と方法}

\section{1. 対象}

1) 平山泌尿器科医院（診療科目：泌尿器科, 腎 臟内科, 性病科, 人工透析, 病床数 : 19 床, 職員 数：常勤医師 3 名, 薬剤師 1 名, 看護師 26 名）を 外来受診している患者.

2) 従来からハルナールロカプセル $0.2 \mathrm{mg}$ を 1 カ 月以上服用後, 剂形変更により口腔内崩壊錠（ハル ナール ${ }^{\circledR} \mathrm{D}$ 錠 $0.2 \mathrm{mg}$ ）を服用している男性患者.

3） PTP 包装のまま調剤し，投薬している患者. 以上の 1)-3）にすべて該当し，かつ本研究の趣旨 を説明した上で, 調査に同意の得られた患者を対象 として意識調査 I， II を実施した.

a）意識調查 I：同意の得られた対象者は 340 名, 平均年齢は $73.2 \pm 7.1$ 歳 $(n=306$, Mean \pm S.D.), 年齢構成は Table 1 に示した.

b）意識調査 II ：同意の得られた対象者は 134 名, 平均年齢は $74.2 \pm 6.9$ 歳 $\quad(n=134$, Mean \pm S.D.)，年齢構成は Table 1 に示した.

\section{2. 方法}

\section{2-1. 意識調査 I}

1）調查期間: 平成 17 年 8 月 22 日から 9 月 22 日の間，意識調査 I を実施した。

2）調査内容: 剂形変更後の排尿時勢いの変化, 排尿回数の変化，体調の変化，ハルナール ${ }^{\circledR} \mathrm{D}$ 錠の 服用性，コンプライアンス状況，自分の性格，年齢 の 7 項目で構成した（Table 2).

3）配布・回収方法：診察終了時及び投薬時に対 象患者に調査用紙を配布し，記入後は当院の薬局に て調査用紙を回収した。回収率は $100 \%$ であった。

\section{2-2. 意識調査 II}

1）調查期間：平成 18 年 2 月 6 日から 2 月 13 日 の間，意識調査 II を実施した.

2）調查内容：口腔内崩壊錠の服用方法，服用 感, 飲夕易さの比較（利便性）, 選択理由, 飲み間 違いとその理由, 併用薬, 塩酸夕ムスロシン服用年 数, 年齢の 8 項目で構成した (Table 3). なお, 八

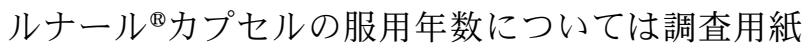
回収後, 患者カルテ内容と照合した.

3）配布 - 回収方法：投薬時若しくは診察終了時 に調査用紙を配布し，聞き取り形式の調査を実施し た. 調査用紙の回収は当院の薬局にて行った. 回収 率は $100 \%$ であった。

なお, 剂形変更時には対象者全員に薬剤情報提供 書のほか, 製薬会社作成の写真付き剂形変更告知文 書を示しながら，「このお薬（ハルナール ${ }^{\circledR} \mathrm{D}$ 錠） の効き目はこれまでのハルナールロカプセルと変わ りなく安全なお薬です。普通のお薬と同じょうに水 で飲んでも結構です．また，水がなくても唾液です ぐに溶けますので舌で押しつぶしながら唾液と一緒 に飲み込んでも結構です.」と説明を加えた.

\section{結果及び考察}

意識調査 I , II の結果を Tables 4-6にそれぞれ示 す.

I-1. 日常のコンプライアンス 意識調査 I に おいて日常のコンプライアンス（ハルナール ${ }^{\circledR} \mathrm{D}$ 錠 以外の処方薬も含む）について尋ねたところ，「薬 の飲み忘れをしない患者（毎日服用する）」が対象 者の $76 \%$ であた。一方，「飲み忘れをする患者」 において飲み忘れの割合は「月に 1,2 回」が $65 \%$

Table 1. Age Compositions of Patients in Survey I, II and Rate of Compliance in Survey I

\begin{tabular}{|c|c|c|c|c|c|c|c|}
\hline 世代 & 50 代 & 60 代 & 70 代 & 80 代 & 90 代 & 未記入 & 平均年齢 \\
\hline $\begin{array}{c}\text { 調査 I } \\
\text { 実施時期 } \\
\text { 平成 } 17 \text { 年 } 8 \text { 月 } 22 \text { 日-9 月 } 22 \text { 日 } \\
(n=340)\end{array}$ & $\begin{array}{c}9 \\
(56 \%) *\end{array}$ & $\begin{array}{c}81 \\
(68 \%) *\end{array}$ & $\begin{array}{c}161 \\
(79 \%)^{*}\end{array}$ & $\begin{array}{c}49 \\
(86 \%)^{*}\end{array}$ & $\begin{array}{c}6 \\
(83 \%)^{*}\end{array}$ & 34 & $\begin{array}{c}73.2 \pm 7.1 \text { 歳 } \\
(\text { Mean } \pm \text { S.D. })\end{array}$ \\
\hline $\begin{array}{c}\text { 調査 II } \\
\text { 実施時期 } \\
\text { 平成 } 18 \text { 年 } 2 \text { 月 } 6 \text { 日-2 月 } 13 \text { 日 } \\
(n=134)\end{array}$ & 1 & 34 & 71 & 6 & 2 & 0 & $\begin{array}{c}74.2 \pm 6.9 \text { 歳 } \\
(\text { Mean } \pm \text { S.D. })\end{array}$ \\
\hline
\end{tabular}

\footnotetext{
* Rate of Compliance.
} 
Table 2. Questionnaire Regimen on Survey I

\section{ハルナール D 錠をお飲みになっている方へのアンケート}

ハルナールの形（かたち）がカプセルから錠剤に変更になって 1 カ月以上が経ちました. 変更後の排尿状態や体調の飲み やすさなどみなさんの現在の状態, ご意見をお聞かせ下さい.

1. お薬の形がカプセルから錠剂に変更になって以降，尿の出に変化がありましたか?
(1. 変わらない
2. 尿の勢いが悪くなつた
3. 尿の勢いがよくなつた）

2. 排尿の回数に変化はありましたか?

（1. 変わらない 2 . 排尿の回数が減つた $\quad 3$. 排尿の回数が増えた）

2 と 3 を選ばれた方にお尋ねします。具体的にはどのように排尿回数が変わりましたか?

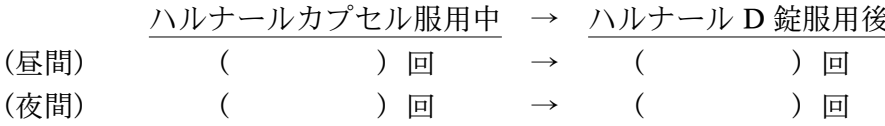

3. 体調の変化はありましたか?

（1．今までと変わらない 2 . 体調の変化があった）

「体調の変化があった」を選ばれた方はどのような体調の変化があったかご記入下さい. (

4. 錠剤（ハルナール D 錠）は以前（ハルナールカプセル）と比べて飲みやすかったですか？
(1. 飲みやすい
2. 飲夕にくい
3. 特に思わない)

5. お薬を飲み忘れることがございますか？
(1. 毎日飲んでいる
2. 飲み忘れることがある)

「飲み忘れることがある」を選ばれた方はお薬の飲み忘れはどのくらいの割合でありますか？
(1. 月に 1,2 回程度
2. 1 週間に 1 回程度
3. 2,3 日に 1 回程度)

6. 毎日の生活, 行動の中で感じるご自分の性格についてお教え下さい.
(1. 几帳面
2. マイペース
3.おおざっぱ
4. 短気
5.おおらか
6. その他)

7. 現在の年齢をご記入下さい.

（）歳

8. その他ご意見等ございましたら自由にご記入下さい，

(

と過半数を占めた. 年代別のコンプライアンス状況 を Table 1 に示した. 70 歳未満と 70 歳以上の患者 群を比較すると, 70 歳以上の患者群のコンプライ アンスが良好であることが判明した。

\section{1-2. 排尿時の勢いおよび体調の変化 調査対} 象者全体の $8 \%$ が排尿時の勢いに変化があったと回 答し，その $3 / 4$ が「排尿の勢いが悪くなった」と疾 病の悪化を訴えた。排尿回数について変化があつた と回答したのは全体の $8 \%$ であり, 内訳は増加・減 少ともに各 $4 \%$ であった。また 3 名が体調の変化を 訴え，その具体的な訴え内容としては「排尿時の痛 み, しびれが出てきたような気がする」，「皮膚のか ゆみが増えた」，「痰がのどにつかえる」であった．

ハルナール ${ }^{\circledR} \mathrm{D}$ 錠とハルナール畂プセルとは生物 学的同等性が確認されている4)た剂形変更後も薬 効は不変であると予測される。調査項目 1-4 はあく までも自覚所見の確認であり，排尿に影響を及ぼす と考えられる併用薬及び QOL（睡眠・水分摂取量
等）調査も実施しておらず，また IPSS スコアや尿 流測定等，薬剤の有効性を評価する試験も実施して いないため客観的な評価はできなかった。意識調査 実施時期が 8-9 月であることも排尿回数に影響を与 えた因子の 1 つであると考えられ，排尿に関する訴 えは剤形変更によるものとは評価し難い.しかし， 病態の変化も考えられるため少数であってもこのよ うな患者の訴えを見逃すことがないよう十分な薬学 的ケアを行う必要がある。具体的には該当患者に対 して再度, カプセル剂と口腔内崩壊錠の生物学的同 等性並びに口腔内崩壊錠の安全性・有効性について 納得いただくまで詳細に説明し，さらに医師とも十 分な協議を行ったうえで他剤への変更または経過観 察とした。体調の変化に関する訴えについてはいず れも $\alpha_{1}$ 受容体遮断薬の主な副作用である血圧低下 及びめまい，ふらつきとはおおよそかけ離れてお り，添付文書にも記載されていない症状であったこ とから日常の患者主訴もしくは他剤による副作用を 
Table 3. Questionnaire Regimen on Survey II

\section{ハルナールの剤形変更に伴うアンケート}

皆さんがお飲みになっているハルナールがカプセルから錠剤に変更されて半年が経ちました. 錠剂の飲みやすさなどにつ

いてご意見・ご感想をお聞かせ下さい.

1. ハルナール D 錠はどのように御飲みになっていますか?

(水なしで飲んでいる・従来通り水で飲んでいる)

2. ハルナール D 錠の味はいかがでしょうか?

(よかった・よくなかった・どちらでもない)

3. 従来のカプセル剤とハルナール D 錠はどちらが飲みやすいですか?

(錠剤が飲みやすい・カプセルが飲みやすい・どちらでもよい)

4. 錠剤またカプセル剂をお選びになった方は選んだ理由をご記入下さい.

(

5. カプセル剤から錠剤に変更になって飲み間違いが多くなりましたか?

(はい・いいえ)

お薬を飲み間違う理由をお選び下さい.

(錠剤の色・薬の形・その他)

6. ハルナール D 錠以外にお飲みになっている薬がありますか?

(ある・ない)

他にお飲みになっている薬の名前がわかればご記入下さい.

(

7. ハルナール（カプセル）を飲み始めてどのくらいになりますか？
( 年
カ月）

8. 現在の年齢をご記入下さい.

( ) 歳

9. その他ご意見があればご自由にお書き下さい.

(

Table 4. The Results on Survey I

\begin{tabular}{|c|c|}
\hline 質問事項 & 果 \\
\hline 1. 剂形変更後の尿の出の変化 $(n=340)$ & 変わらない $92 \%$, 勢いが悪くなつた 6\%, 勢いがよくなつた $2 \%$ \\
\hline 2. 剂形変更後の排尿回数の変化 $\quad(n=340)$ & 変わらない $92 \%$, 排尿回数が減つた $4 \%$, 排尿回数が増えた $4 \%$ \\
\hline 3. 剂形変更後の体調の変化 $(n=338)$ & 変わらない 99\%，変化があつた 1\% \\
\hline 4. ハルナール D 錠の飲みやすさ $(n=340)$ & 特に思わない $52 \%$, 飲みやすい $41 \%$, 飲みにくい $7 \%$ \\
\hline 5. (1)薬の飲み忘れ $(n=340)$ & 毎日飲んでいる 76\%，飲み忘れることがある 24\% \\
\hline (2)飲み忘れの頻度 $(n=83)$ & 月に 1-2 回 $65 \%, 1$ 週間に 1 回 $33 \%, 2,3$ 日に 1 回 $2 \%$ \\
\hline 6. 自分の性格 $(n=306)$ & $\begin{array}{l}\text { マイペース } 36 \% \text {, 几帳面 } 29 \% \text {, おおざっぱ } 13 \% \text {, 短気 } 8 \% \text {, おおら } \\
\text { か } 8 \% \text { ，その他 6\% }\end{array}$ \\
\hline
\end{tabular}

Table 5. The Results on Survey II

\begin{tabular}{|c|c|}
\hline 質問事項 & 結 \\
\hline 1. ハルナール D 錠の服用方法 & 水なしで服用している 8\%，水で服用している 92\% \\
\hline 2.ハルナールの服用感（味） & よかつた 7\%, よくなかつた 3\%, どちらでもない 90\% \\
\hline 3. カプセル剂と錠剂の飲みやすさの比較 & 錠剂がよい 49\%, カプセル剂がよい 14\%, どちらでもよい $37 \%$ \\
\hline 4. 錠剂もしくはカプセル剂を選んだ理由 & Table 6 参照 \\
\hline 5. 剂形変更後の飲み間違いが多くなったか & はい 16\%, いいえ $84 \%$ \\
\hline 飲み間違いが多くなった理由 & 錠剂の色 $71 \%$ ，錠剂の形 $24 \% ，$ 錠剂の色・形 $5 \%$ \\
\hline 6. ハルナール D 錠以外に服用している薬剤の有無 & ある 97\%,なし 3\% \\
\hline
\end{tabular}


Table 6. The Reasons for Selecting Capsule or Tablet as a Favorite Dosage Form

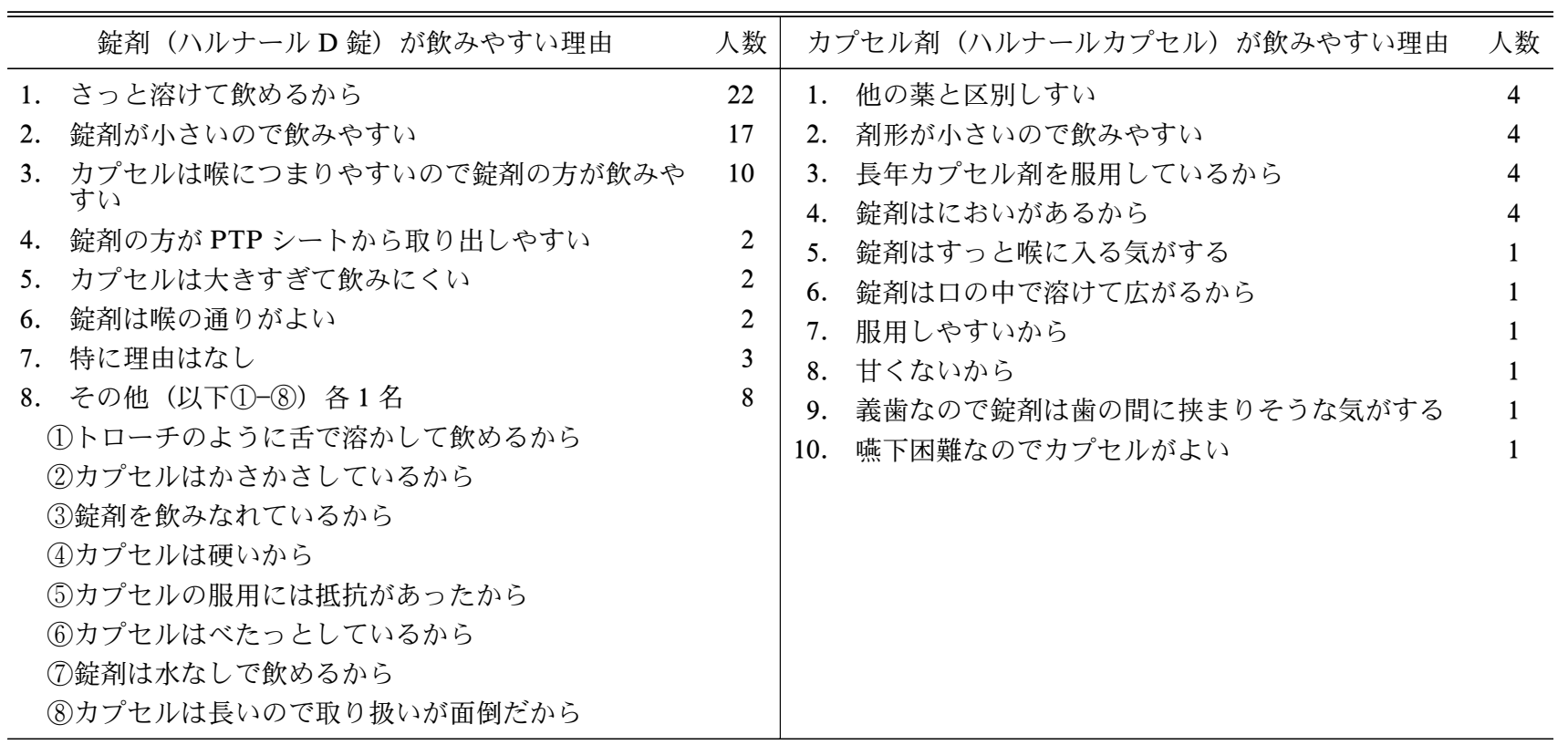

記入した可能性が高いと推測された。

\section{I-3. ハルナール ${ }^{\circledR} D$ 錠の服用性口腔内崩壊} 錠の有用性について検討した複数の報告 ${ }^{5-7)}$ では, 大半の患者が服用し易いと回答している，ハルナー ル®カプセルと比較したハルナール ${ }^{\circledR} \mathrm{D}$ 錠の服用性 について本調査では「飲み易い」と回答した患者 (41\%) が「飲み難い」と回答した患者（7\%）を大 きく上回っていたものの「特に思わない」が $52 \%$ を占めていた。 ところで，飲み難い理由としては設 問の中には設定しなかったが，「その他の意見」の 中にハルナール ${ }^{\circledR} \mathrm{D}$ 錠が飲み難い理由として (1)他の 薬と間違い易い，(2)長くカプセル剂を服用していた ので戸惑った，(3)色が白なので効き目がないような 気がする等の剂形・色に対する不安と，(4)甘くて好 きではない，薬という気がしない，(5)カプセルの方 がすぐに溶けるのでよい，6錠剤は湿気があるので カプセルがよい等，個人的啫好が記載されていた. 「飲み難い」と訴えた患者では，口腔内崩壊錠を服 用することだけでなく，これまで服用していたカプ セル剂を服用できなくなることに不安を感じている ことが示唆された。平成 18 年 9 月の時点で市場に は 17 種類の口腔内崩壊錠（先発品）が発売されて いる．ハルナール ${ }^{\circledR} \mathrm{D}$ 錠以外の薬剤は，錠剤若しく はカプセル剂と口腔内崩壊錠の 2 種類があるため患 者の嗜好に合わせた剂形選択が可能である。一方， ハルナール®につては，カプセル剂が市場から消
え口腔内崩壊錠のみとなってしまった。朴はハル ナール ${ }^{\circledR} \mathrm{D}$ 錠への剂形切り替えはおおむねよいもの であり，また切り替えによる有効性への影響もない

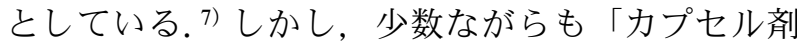
がよかった」と新規剂形への切り替えに対して抵抗 を示す患者が存在したことから剤形切り替えが患者 に動摇を与えたことにわれわれは留意すべきである.

I-4. 患者個々の性格 患者個々の性格が排尿 状態，体調の変化と心理的に関係があるのではない かと考え，6つのタイプの性格を列挙し選択しても らったが，性格と排尿状態等との間に関係は見い出 せなかつた。

II-1. ハルナール ${ }^{\circledR} D$ 錠の服用方法 ハルナー ル ${ }^{\circledR} \mathrm{D}$ 錠を水なしで服用している患者は $8 \%$ ，残り の $92 \%$ は水で服用していることが分かった。この 背景には他剂同時服用が考えられる。実際，水なし で服用している患者の平均併用薬剂数は $2.1 \pm 1.0$ 剂，水で服用している患者は $3.1 \pm 2.7$ 剂と水で服 用している患者の併用薬剂数は多く，この結果は他 の口腔内崩壊錠の服用性についての報告3) と同様な 傾向を示した。またハルナール ${ }^{\circledR} \mathrm{D}$ 錠を水なしで服 用している患者の平均年齢は $65.3 \pm 3.5$ 歳，水で服 用している患者は $75.0 \pm 6.9$ 歳であった．斉田らの 意識調査によると口腔内崩壊錠を薬効別にみた場 合，ベイスン ${ }^{\circledR} \mathrm{OD}$ 錠，レンドルミン ${ }^{\circledR} \mathrm{D}$ 錠，ゾーミ ック ${ }^{\circledR} \mathrm{RM}$ 錠は服用方法がそれぞれ食直前，就寝 
前，屯用に限定され同時服用剂数が少ないため口腔 内崩壊錠の利便性が生かされ有用であったとしてい る. ${ }^{8)}$ 平成 18 年 9 月現在, 市販されている 17 種類 のうち $5-\mathrm{HT}_{3}$ 受容体拮抗型制吐剂, 片頭痛治療 薬，睡眠導入剂，糖尿病食後過血糖改善剤は服用方 法が限定されているため，「水なしでも服用可能」 という口腔内崩壊錠の利便性を最大限に活かすこと ができると思われる。一方，ハルナール ${ }^{\circledR} \mathrm{D}$ 錠をは じめとするその他の口腔内崩壊錠は服用方法が限定 されておらず他剤との同時服用も考えられる，本調 査でも明らかになったように対象患者の 97\%は併 用薬剤があり，水なしで服用される機会は少なかつ た．しかし，薬剤を複数併用する場合，併用薬剤数 が増えれば増えるほど処方中に口腔内崩壊錠が 1 種 類でも含まれていると，特に嚥下力が低下している 高齢者では服薬の際のリスク軽減につながることが 予期され，処方医も「水なしでも服用可能」という 利点以外の有用性を期待して処方している場合も多 いようである.9

\section{II-2. ハルナール ${ }^{\circledR} D$ 錠の服用感「ハルナール ${ }^{\circledR}$} $\mathrm{D}$ 錠の味はよかったですか」という問いに対して, 対象患者の $90 \%$ が「どちらでもない」と回答した。 その理由として，水を必要とする薬の同時服用が考 えられた。「よかった」と回答した患者は 7\%と少 数であり，そのうち「甘くて飲み易い」という意見 が 3 例あった。口腔内崩壊錠の素材の中心は糖類で あり，ハルナール ${ }^{\circledR} \mathrm{D}$ 錠には味・食感などの理由に より清涼感のあるマンニトールが使用されてい る10)。しかし，逆にその甘さが飲み難い理由にも挙 げられており，服用感については個人の嗜好が関与 してくるものと思われた.

II-3. 剂形の嗜好錠剤（口腔内崩壊錠）がよ いと回答した患者は $49 \%$ と約半数を占め, どちら でもよいと回答した $37 \%$ を回った。 その理由と して「さっと溶けて飲み易いから」が 1/3（22 名） を占めた。 口腔内崩壊時間は 1 分以内であれば日常 生活上ほとんど問題ないと考えられている10)が，他 の口腔内崩壊錠と同様にハルナール ${ }^{\circledR} \mathrm{D}$ 錠も 30 秒 以内で崩壊し，燕下という点では全く問題がないと 考えられた。しかし，剂形変更時に服薬指導を行つ たにも係わらずカプセル剤を好んだ患者の中には， 「錠剂はさっと喉に入って誤嚥しそうな気がする」, 「燕下困難なのでカプセルがよい」との回答もあつ
た。口腔内崩壊錠という剤形について，このように 一部の患者で十分な理解が得られていないことが分 かった。また，「錠剤の方が飲み易い」と回答した 患者の $30 \%$ が崩壊性ではなく「錠剤が小さいので 飲み易い」，「カプセルは大きいので飲み難い」，「カ プセルは長いので取り扱いが面倒」と剂形の大きさ を理由に挙げた。以上の結果から，錠剂が飲み易い と回答した患者は服用性を重視しており，剂形選択 に当たり製剤の大きさも崩壊性の次に重要な要素で あることが示唆された。一方，カプセル剂が服用し 易いと回答した患者は $14 \%$ であった。カプセル剂 は服用時に喉につかえ易いなどの問題点が指摘され ているにも係わらず飲み易い主な理由として挙げら れたのは，「他の薬と区別がし易いから」，「カプセ ルの方が尿の出がよいから」,「長年カプセル剂を服 用しているから」と服用性に係わる以外の理由であ った（Table 6)。色つきのカプセル剂は他剤との区 別がつき易く，白内障などの視覚障害を持つ高齢者 にとって服用性よりも確実に薬剤の認識ができるこ との方が重要な要素である．また「カプセルの方が 尿の出がよいから」，「長年カプセル剂を服用してい るから」という回答は，剂形の嗜好よりもむしろ， 「ハルナール衴プセルは尿の出をよくする薬」とい う先入観も影響しているのではないかと思われる.

\section{II-4. 剂形変更によるコンプライアンスへの影響}

剂形変更後, 飲み間違いが増えたという回答が 16\%あった。飲夕間違いが増えた患者にその理由を 尋ねたところ，「色」が $71 \%$ ，「形」が $24 \%$ であっ た。飲み間違いが増えた原因として，1）色つきの力 プセル剤から他剤と見分けのつき難い白色に色調が 変更されたこと，2) カプセル剂から剂形の異なる錠 剤に変更されたことが挙げられる，具体的には「色 が白色に変更されたため他の薬と区別ができず 1 日 3 回飲んでしまった」という回答もありコンプライ アンスへの影響が示唆された。

II-5. 塩酸タムスロシン以外の併用薬 ハル ナール ${ }^{\mathbb{D}}$ 錠以外の併用薬（当施設以外からの処方 薬も含む）について調査した結果，調査対象者全体 の $97 \%$ がハルナール ${ }^{\circledR} \mathrm{D}$ 錠以外の薬剤も服用してお り, 平均併用薬剂数は $2.3 \pm 1.0$ 剂であった. 世代 別の内訳では 70 代が $3.3 \pm 2.8$ 剂と一番多かった. 当施設においては, ハルナール ${ }^{\circledR} \mathrm{D}$ 錠以外の泌尿・ 生殖器用薬等が併用処方されることが多い。いずれ 
も色・錠剤の大きさともにハルナール ${ }^{\circledR} \mathrm{D}$ 錠と類似 しており，PTP シートから外した場合には飲み間 違いをする可能性が高いことが考えられた。

\section{総括}

以上，意識調査 I （剂形変更後 1 力月後実施）と 意識調查 II (剂形変更後 6 力月後実施) の結果より, 対象患者が「錠剤の方が飲み易い」と回答した割合 はそれぞれ $41 \%$ ，49\%で類似した值となった。一 方，主に色調や剂形に起因した飲み間違いが誘発さ れ，患者の服薬コンプライアンスに影響を与えた. また少数であったが不安を感じ体調（排尿状態）変 化を訴えた患者が存在したことが明らかとなった。 ハルナール ${ }^{\circledR} \mathrm{D}$ 錠服用患者の大半は 60 歳以上であ るため, このような剂形変更の際には薬剤師として 患者に対して水なしでも服用できる利便性よりも, 患者背景を考慮した上で一人一人が安全かつ有効な 薬物療法を長期間継続できることを重視した服薬指 導を実施する必要がある。ささらに患者の不安の解消 のためには狭義の服薬指導に留まらず，定期的に処 方内容・副作用・効果の確認を十分に行い，処方に 反映させることが安全で有効な薬物療法の徹底につ ながると考える．また錠剤の識別性については医療 過誤防止，高齢者の視覚障害等への配慮からハル ナール ${ }^{\circledR} \mathrm{D}$ 錠に限らず，すべての剂形において重要 性の高い特色である。今後, 製剤開発の際は高齢化 社会を視野に入れ，他剤との識別性向上のために，
形状・着色・表示など多方面より製剂設計を検討す る必要があると思われた.

\section{REFERENCES}

1) Yoshida O., "Bedside Urology Second Edition," Nankodo, Tokyo, 1992, pp. 407-417.

2) Honda Y., Nakano M., Jpn. J. Hosp. Pharm., 24, 533-540 (1998).

3) Yago K., Kuroyama M., Otori K., J. New Remed. Clin., 47, 14-17 (1997).

4) Interview Form, Second Edition, "Harnal ${ }^{\circledR}$ D" (2005).

5) Nakayama O., Torii Y., Noda T., Jpn. J. Cancer Chemother., 28, 1121-1127 (2001).

6) Tanaka E., Kuzutani T., Onishi A., Chiba K., Noda Y., Nabeshima T., Jpn. J. Pharm. Health Care Sci., 31, 146-150 (2005) .

7) Boku E., Jpn. Pharmacol. Ther., 34, 387-394 (2006).

8) Saita Y., Shinohara T., Tsutumi M., Nishimoto J., Ishibashi H., Tominaga K., Miki A., Ohtani H., Sawada Y., Abstracts of papers, the 36th Japan Pharmaceutical Association Congress of Pharmacy and Pharmaceutical Science, Hiroshima, October 2005, p. 272.

9) Shiga Y., Kaneko H., Fujiwara K., J. Blood Pressure, 13, 911-916 (2006).

10) Masuda Y., Pharm. Tech. Jpn., 22, 403-412 (2006). 